\title{
Analytical Review on the Trends and Present Situation of Large-scale Sustainable Energy Storage Technology
}

\author{
Arslan Habib ${ }^{1 *}$, Chan Sou 2 \\ ${ }^{1}$ Northwestern Polytechnical University, CHINA \\ 2 State Grid Tianjin Energy Saving Service Co., Ltd, CHINA \\ *Corresponding Author: arslan.2010@live.com \\ Citation: Habib, A. and Sou, C. (2018). Analytical Review on the Trends and Present Situation of Large- \\ scale Sustainable Energy Storage Technology. European Journal of Sustainable Development Research, 2(3), 31. \\ https://doi.org/10.20897/ejosdr/86200
}

Published: July 9, 2018

\begin{abstract}
Energy storage technology is to achieve large-scale access to renewable energy sources; the key technology for improving efficiency, safety and economy of power systems is also to increase the ratio of clean energy to power generation, and effective means of promoting haze governance. By the end of 2015, the total installed capacity of the global energy storage equipment was about $167 \mathrm{GW}$, about $2.9 \%$ of the world's total installed power; the energy storage equipment in China is $22.8 \mathrm{GW}$, about $1.7 \%$ of the total installed power of the country. By 2050, China's energy storage equipment will reach $200 \mathrm{GW}$; the market size will reach more than 2 trillion RMB. The existing energy storage technologies include pumped storage, compressed air energy storage, flywheel energy storage, superconducting storage, lead-acid batteries, lithium batteries, sodium sulfur batteries, liquid flow batteries and super capacitors. Different energy storage technologies are applicable to different applications and fields, depending on system power and discharge time, the main application areas of energy storage technology can be divided into three parts: energy management, power bridging and power quality management. Future energy storage market development will focus on distributed energy storage, distributed photovoltaic PV + energy storage, Micro grid, distribution network side and user side and other fields. In recent years, China's energy storage industry has accelerated the pace of development in terms of project planning, policy support and capacity layout, in the next few years, with the rapid development of renewable energy industry, the energy storage market will also enjoy rapid growth. However, the energy storage industry in this country is still in the initial stage of development, and it is mainly based on demonstration and application, the commercial application of energy storage faces the high cost of storage and the imperfect market of power exchange. Energy storage technology route is not mature, lack of energy storage, effective price and effective incentives are both opportunities and challenges.
\end{abstract}

Keywords: energy storage technology, energy storage installation, application area, distributed energy storage, renewable energy, commercialization

\section{INTRODUCTION}

Energy storage is the process of storing energy by means of a medium or device and releasing it when needed. Energy storage technology is the key technology to solve the problems of large scale access of renewable energy sources, abandonment of air and waste of light; It is an essential technology for the development of distributed energy, smart grid and energy network; It is also an important support technology to solve the problems of 
conventional power peak shaving and valley filling, and to improve the conventional energy power generation and transmission efficiency, safety and economy. Energy storage technology can improve the proportion of clean energy power generation, and thus achieve clean and efficient use of fossil fuels, effectively reduce pollutant emissions, haze and other environmental issues and improve the living environment will play a great role in its promotion. At the same time, the development of energy storage technology is related to the development of many important industries, such as energy, transportation and electricity, especially in today, energy depletion is becoming more and more acute. Energy consumption imbalance between supply and demand, energy storage can break through the traditional energy model, time and space constraints, its important role has become increasingly prominent, and has become a strategic emerging industry in the major developed countries (Chen et al., 2009; Energy Storage Council, 2002; Luo et al., 2015; Zhang et al., 2012; Ming et al., 2013). Here, China's energy resources are large, but the energy structure is complex and has a certain particularity, the energy resources of the northwest region are rich, but the demand is low, the population in the southeast is dense, the energy demand is large, and the energy and the demand exist the regional dislocation (Northwest Institute of Surveying and Design Limited, 2014; Ma, 2014). The energy storage industry is the key to the transformation of energy structure and push hands to speed up the development of energy storage industry, it is of great significance for promoting economic development and building a healthy energy output and consumption system (Mi, 2014; International Energy Agency, 2014). Based on the active distributed network security constraints, the market price guide, coordination of DG (Distributed Generation), energy storage and load and other benefits are important means to promote the utilization rate of Distributed Renewable Energy (Habib et al., 2017). At this stage, the community's understanding and importance of energy storage technology and industry are gradually deepening, more and more professional and commercial investors believe that the development of the energy storage industry is essential for the development of all sectors of the national economy. At the same time, government departments also promote the development of energy storage technology and industry through scientific and technological innovation and a variety of incentives, through the deployment of a number of funding projects and demonstration projects, and gradually cultivate and promote the commercial application of energy storage technology (Zhongguancun, 2012).

\section{MAJOR ENERGY STORAGE TECHNOLOGY}

The existing energy storage technologies include pumped storage, compressed air energy storage, flywheel energy storage, superconducting storage, lead-acid batteries, lithium batteries, sodium sulfur batteries, liquid flow batteries and super capacitors.

(1) The pumped storage power station sends water from the lower reservoir to the upper reservoir at the trough of power consumption, Thus, the electric energy is converted into the potential energy of water to be stored; when the electricity is used, the gravitational potential energy of the water drives the water turbine to generate electricity.

(2) The principle of compressed air energy storage system is that the air is compressed in the air storage chamber at the lowest point of power consumption, so that the energy can be stored into the internal energy of the air; at the peak of the use of electricity, high pressure air is released from the storage chamber to drive the turbine to generate electricity.

(3) Flywheel energy storage is to store energy in the form of rotational kinetic energy of the flywheel. When charging, the flywheel is driven by the motor to rotate at full speed. When discharging, the same motor is used as a generator, and the rotating flywheel drives the electric energy.

(4) Superconducting energy storage is the current into the ring inductance coil, because the ring inductance coil made of superconducting material, so the current in the coil can achieve the purpose of energy storage without loss of continuous circulation.

(5) The lead acid battery works by discharging electricity, lead two of the positive electrode reacts with sulfuric acid to produce lead sulfate and water; the lead of the negative electrode reacts with sulfuric acid to produce lead sulfate; When charging, the lead sulfate of the positive electrode is converted into two lead oxide, and the lead sulfate of the negative lead is converted into lead.

(6) The lithium battery works by charging the lithium atom into lithium ions, the carbon is transferred through the electrolyte and stored as a lithium atom after binding of the carbon electrode to the external electrons; when discharging, the whole process is reversed.

(7) The positive and negative electrolytes in the flow battery are separated by an ion conducting membrane, when the battery is working; the active material ions in the electrolyte change on the valence surface of the inert electrode, and then complete the charge and discharge.

(8) When the sodium sulfur battery discharges, sodium ions pass through the electrolyte, and electrons flow through the external circuit to generate voltage; when charging, the whole process reverses, and the sodium polysulfide releases the sodium ion, which is reversed to the sodium through the electrolyte. 


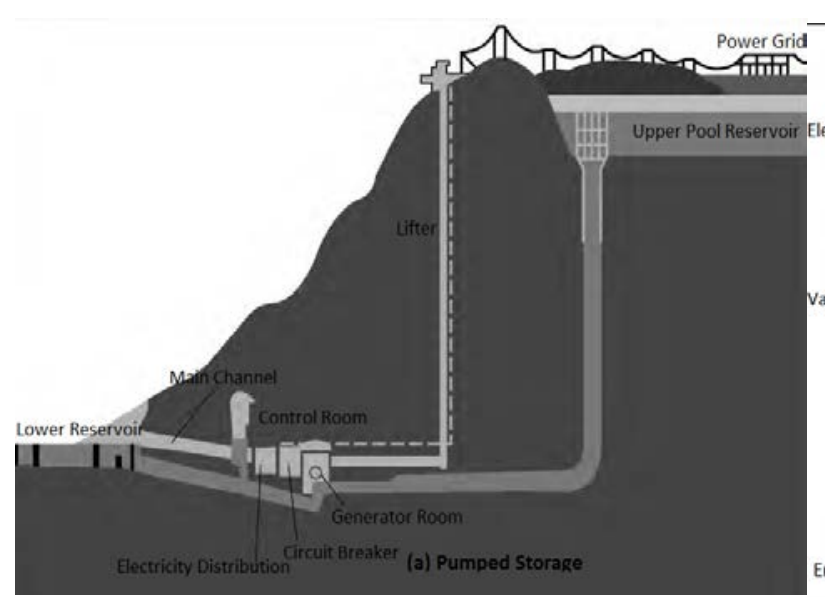

(a) Pumped Storage

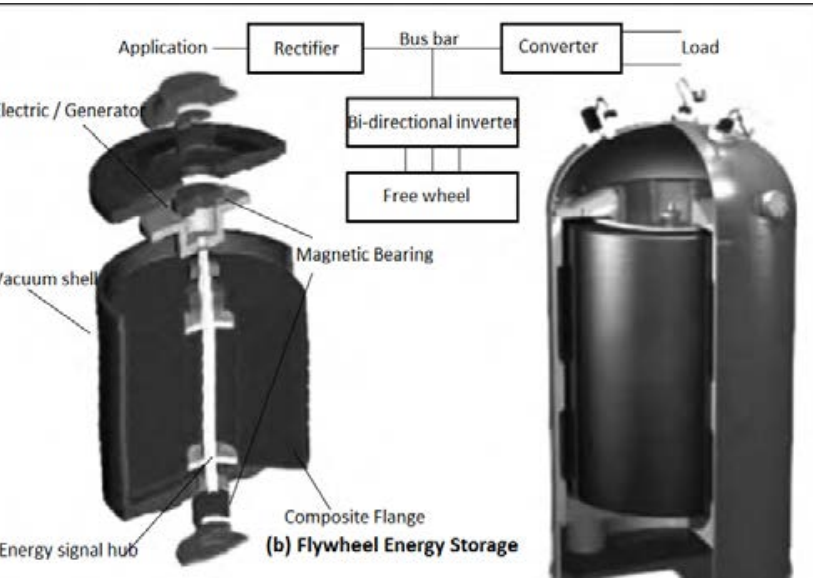

(b) Flywheel Energy Storage

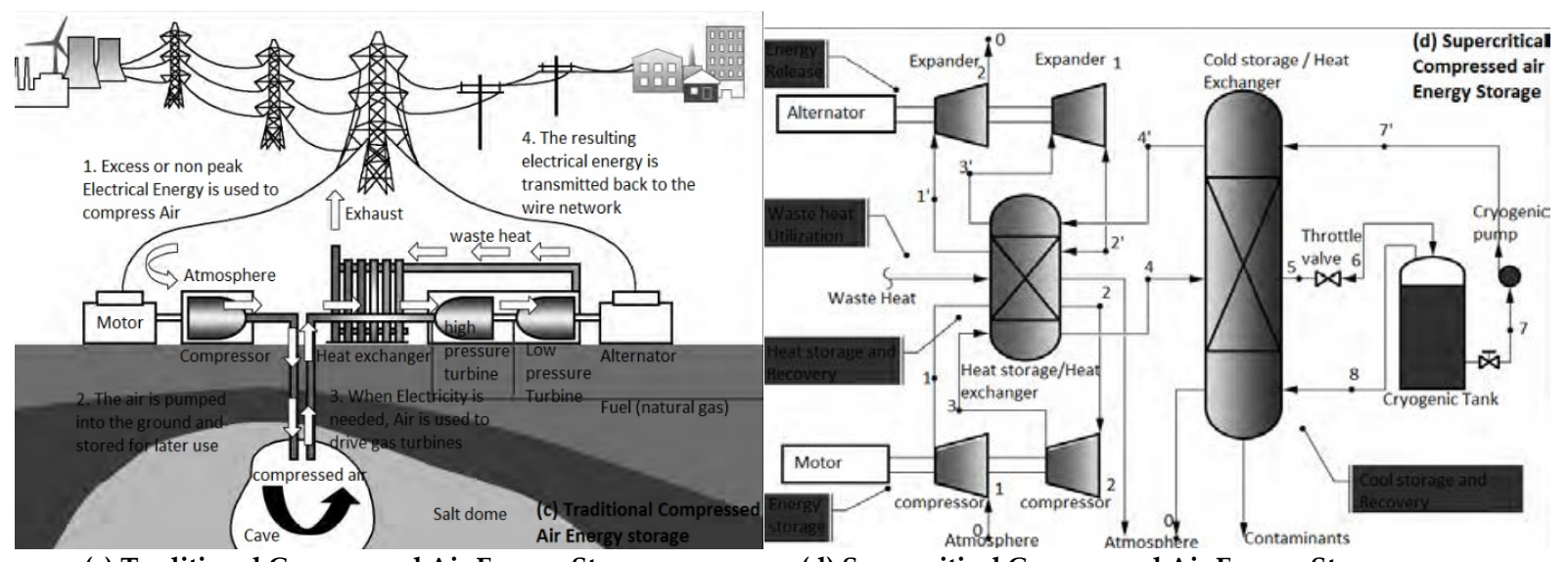

(c) Traditional Compressed Air Energy Storage

(d) Supercritical Compressed Air Energy Storage

Figure 1. Schematic Diagram of Main Energy Storage Technology

(9) The super capacitor is based on the double layer capacitance of the porous carbon electrode / electrolyte interface, alternatively, a Quasi-capacitor based on a fast and reversible Faraday reaction on the surface of a metal oxide or conductive polymer is used to achieve energy storage.

The principle of each kind of energy storage technology is shown in schematic Figure 1, and the main technical parameters are compared with Table 1 (Chen et al., 2009; Energy Storage Council, 2002; Luo et al., 2015).

\section{KEY TECHNOLOGIES AND DEVELOPMENT THREND OF ENERGY STORAGE}

Different energy storage technologies have different concepts and principles, so their key scientific problems and technical difficulties are different; Table 2 presents the key technologies and development trends of different energy storage technologies. The maturity of various energy storage technologies in China is different, and they are all at different stages of development (see Table 3) (Chen et al., 2009; Energy Storage Council, 2002; Luo et al., 2015; Zhongguancun, 2012; Zhongguancun, 2013; Zhongguancun, 2014; Zhongguancun, 2015; Special report, 2016).

\section{APPLICATION ANALYSIS OF ENERGY STORAGE TECHNOLOGY}

Different energy storage technologies have different performance characteristics, and are suitable for different applications and fields. In the energy storage planning report issued by the US Department of energy, according to the system power and discharge time of different energy storage technologies, the applicable areas of energy storage technology are analyzed. The main application areas of energy storage technology can be divided into three parts: energy management, power bridging and power quality management, as shown in Figure 2, (The U.S. Department of Energy, 2011). Among them, pumped storage and compressed air energy storage are recognized as energy storage technologies which can be applied to large scale (class 10MW or above) and can be applied to the power grid side to replace the expensive peak shaving power, so as to achieve the purpose of energy management. At the same time, some storage technologies have some potential in other applications of power 


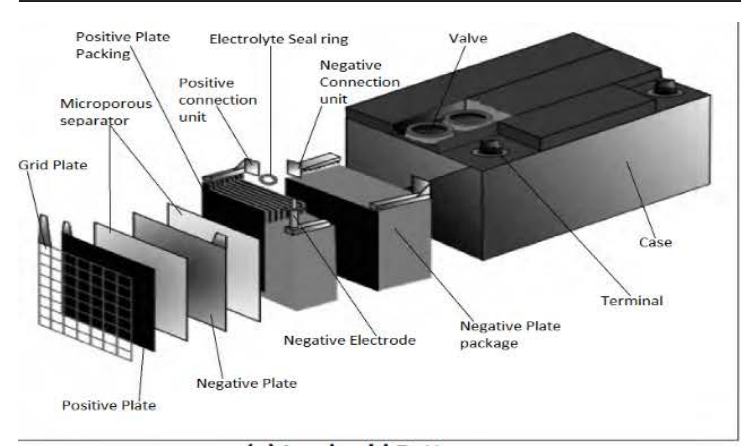

(e) Lead-acid Battery
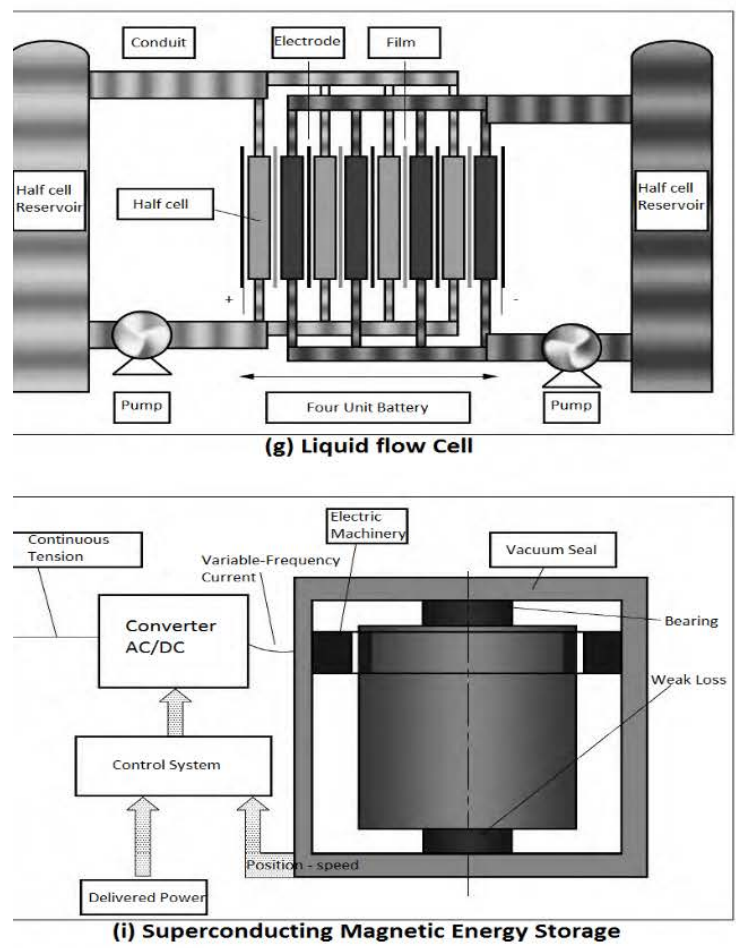

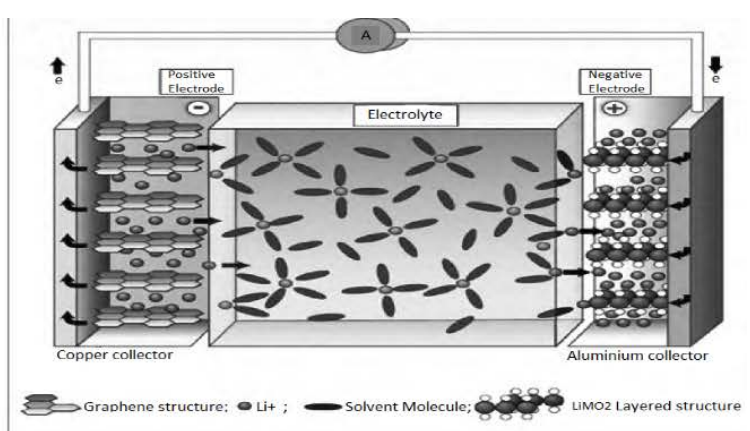

(f) Lithium Battery

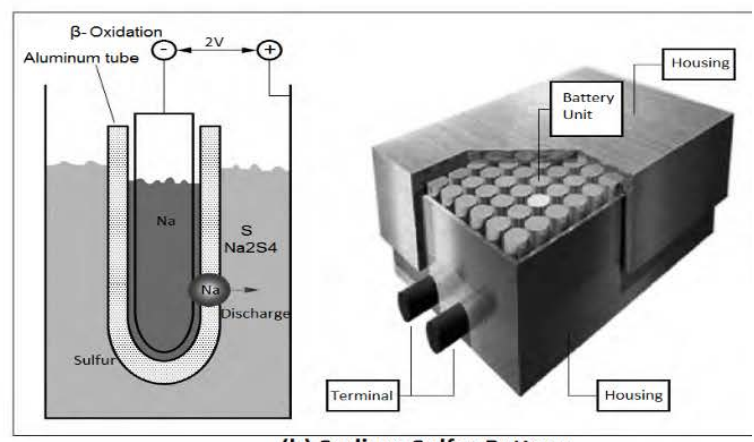

(h) Sodium Sulfur Battery

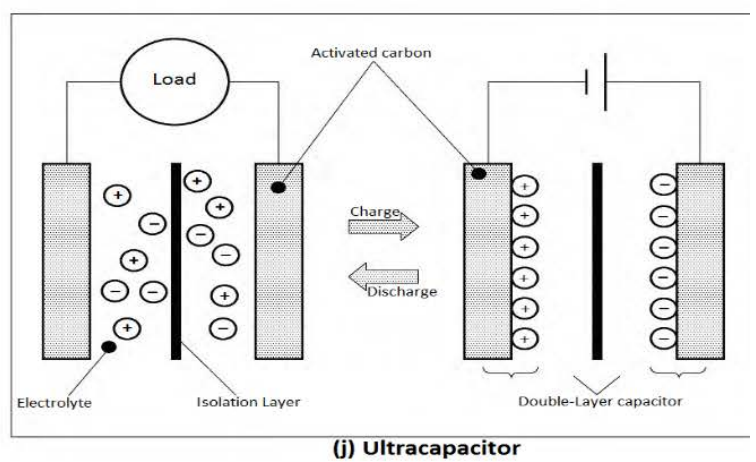

Figure 1 (continued). Schematic Diagram of Main Energy Storage Technology

grid, such as lead-acid batteries, lithium batteries, liquid flow batteries, sodium sulfur batteries and high-energy super capacitors and other chemical energy storage technologies. The power range of the system is usually from 1 $\mathrm{kW}$ to $10 \mathrm{MW}$, and the discharge time is mostly minutes, so it is mainly used in the field of power grid, such as short time power system peaking and energy scheduling. The flywheel, super capacitor and superconducting energy storage technology have fast response, and the system power and discharge time are smaller. These are very flexible, generally used in the field of power quality management, such as ancillary services and voltage support. In, Control Strategy of DC Link Voltage Flywheel Energy Storage for Non Grid Connected Wind Turbines Based on Fuzzy

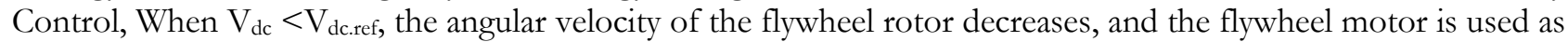
the generator. The flywheel energy storage system converts the mechanical energy into electrical energy, and the DC bus capacitor is provided to improve the DC bus voltage. When $V_{d c}>V_{d c . r e f}$, the angular speed of the flywheel rotor rises and the flywheel motor acts as the motor. The flywheel energy storage system absorbs excess energy from the intermediate bus capacitor, convert into mechanical energy, and stored in the flywheel rotor (Habib et al., 2017).

Specifically, the energy storage technology has different applications in all aspects of power transmission, distribution and application, as shown in Table 4, (Chen et al., 2009; Energy Storage Council, 2002; Zhongguancun, 2012; Zhongguancun, 2013). In the power generation side, the traditional power generation field can perform auxiliary dynamic operation to replace or delay the new unit; In the field of renewable energy power generation, it is mainly used for peak shaving, valley filling, tracking project output and ramp rate control; The main applications in the field of power transmission and distribution include reactive power support, link blocking, delayed expansion of power transmission and distribution, as well as DC power supply for substations; Mainly used in the field of power grid ancillary services including frequency, voltage, peak and support as a spare capacity; at the same time, the energy storage technology can be used for time-sharing price and capacity cost management at the user side, improve power reliability and power quality, as well. 
European Journal of Sustainable Development Research, 2(3), 31

Table 1. Comparison of Main Energy Storage Technical Parameters

\begin{tabular}{|c|c|c|c|c|c|c|c|c|}
\hline $\begin{array}{l}\text { Energy storage } \\
\text { technology }\end{array}$ & $\underline{\text { Scale/MW }}$ & $\frac{\text { Storage }}{\text { cycle }}$ & $\begin{array}{c}\text { Full power } \\
\text { response time }\end{array}$ & Efficiency $\%$ & $\begin{array}{c}\frac{\text { Energy storage }}{\text { density }\left[(W \cdot h) \cdot L^{-}\right.} \\
1]\end{array}$ & Life/a & $\frac{\text { Power cost }}{/\left(\mathrm{kW}^{-1}\right)}$ & $\frac{\text { Energy cost/ }}{\left[(\mathrm{kW} \cdot \mathrm{h})^{-1}\right]}$ \\
\hline Pumped storage & $100 \sim 5000$ & $\begin{array}{c}\text { Hours to } \\
\text { months }\end{array}$ & Minute level & $70 \sim 80$ & $0.2 \sim 2$ & $40 \sim 60$ & $4500 \sim 5500$ & $1000 \sim 1500$ \\
\hline Compressed air & $1 \sim 300$ & $\begin{array}{c}\text { Minutes to } \\
\text { months }\end{array}$ & Minute level & $60 \sim 70$ & $3 \sim 100$ & $30 \sim 40$ & $6500 \sim 7000$ & $1500 \sim 2500$ \\
\hline Free wheel & $0.1 \sim 10$ & $\begin{array}{l}\text { Seconds } \\
\text { to minutes }\end{array}$ & Ten millisecond & $80 \sim 95$ & $20 \sim 80$ & $5 \sim 20$ & $1700 \sim 2000$ & $\sim 45500$ \\
\hline Superconductivity & $0 \sim 1$ & Seconds & Millisecond level & $90 \sim 97$ & $\sim 6$ & $>20$ & $6500 \sim 7000$ & $\sim 90000$ \\
\hline Lead acid battery & $0.1 \sim 20$ & $\begin{array}{l}\text { Minutes to } \\
\text { days }\end{array}$ & Millisecond scale & $65 \sim 80$ & $50 \sim 80$ & $5 \sim 8$ & $500 \sim 1000$ & $800 \sim 1300$ \\
\hline Lithium battery & $0.1 \sim 32$ & $\begin{array}{c}\text { Minutes to } \\
\text { days }\end{array}$ & Millisecond scale & $85 \sim 98$ & $200 \sim 400$ & $8 \sim 10$ & $3200 \sim 9000$ & $1600 \sim 4500$ \\
\hline Liquid flow cell & $0.1 \sim 500$ & $\begin{array}{l}\text { Hours to } \\
\text { months }\end{array}$ & Millisecond scale & $65 \sim 75$ & $20 \sim 70$ & $5 \sim 15$ & $12500 \sim 19500$ & $2500 \sim 3500$ \\
\hline $\begin{array}{l}\text { Sodium sulfur } \\
\text { battery }\end{array}$ & $0.1 \sim 50$ & $\begin{array}{l}\text { Seconds } \\
\text { to hours }\end{array}$ & Millisecond scale & $70 \sim 80$ & $150 \sim 300$ & $\sim 15$ & $13200 \sim 13800$ & $2200 \sim 4000$ \\
\hline Ultra capacitor & $0 \sim 1$ & Seconds & Millisecond level & $60 \sim 90$ & $10 \sim 20$ & $\sim 15$ & $400 \sim 500$ & $9500 \sim 13500$ \\
\hline
\end{tabular}

\section{DEVELOPMENT STATUS AND DEVELOPMENT TREND OF ENERGY STORAGE INDUSTRY}

China's energy storage industry is still in the initial stage of development, mainly in demonstration and application, and there is still a gap compared with the industrialization process of developed countries. By the end of 2015, the total installed capacity of the global energy storage equipment was about $167 \mathrm{GW}$, accounting for about $2.9 \%$ of the total power installed capacity of the world. The energy storage equipment in China was $22.8 \mathrm{GW}$, accounting for about $1.7 \%$ of the total installed capacity of the whole country. According to the International Energy Agency (IEA), by 2050 it is expected that the global energy storage capacity will reach more than 800GW, and China's energy storage capacity will reach $200 \mathrm{GW}$ by 2050, and the market scale will reach more than 2 trillion yuan. The demand for energy storage in China is huge and urgent.

In the field of physical energy storage, pumped storage and compressed air energy storage are the two fastest growing energy storage technologies. Pumped storage is the largest energy storage technology in the world, accounting for $98 \%$ of the total energy storage capacity of the world, and Japan, China and the United States are among the top three in the world (Zhang et al., 2010; Rosasa et al., 2013; Xiaohui et al., 2013). The size of pumped storage unit has reached 300MW, and it is the most mature energy storage technology. Compressed air energy storage has now been used in large-scale commercial applications in Germany (Huntorf, 321MW) and the United States (McIntosh, 110MW, Ohio, 9×300MW, Texas, 4×135MW and Iowa 200MW projects) (Chen et al., 2009; Luo et al., 2015; Critigino et al., 2001; Nakhamkin et al., 1990; Liu et al., 2007). In the new type of compressed air energy storage, only the International Academy of Sciences Institute of Engineering Thermophysics (1.5MW, compressed air energy storage, 10MW advanced compressed air energy storage), American General Compression Corporation (2MW regenerative compressed air energy storage), American SutainX Corporation (1.5MW isothermal compressed air energy storage), And the British High view Power company (Megawatt liquid air energy storage) 4 institutions with megawatt production design capabilities. Energiestro has recently invented a fly wheel energy storage with much low cost material (Chino et al., 2000; Chen et al., 2008; Chen et al., 2012; Guo et al., 2016). In the China's R \& D and industrialization of compressed air energy storage technology, the Institute of Engineering Thermophysics in China is absolutely in the lead. The Institute completed the first international 1.5MW demonstration system in 2013, and realized industrialization. In 2016, it built the only 10MW research and development platform in the world. At the same time, also approved the construction of national energy largescale physical energy storage technology research and development center, the relevant results won the first prize in Beijing science and technology award, United Nations Industrial Development Organization, global renewable energy sector, the most valuable investment in leading technology, "Blue sky Award" and so on.

In the field of chemical energy storage, lead acid battery has the advantages of early molding and low material cost, is by far the most mature chemical battery, as of 2015, the world's energy storage capacity of lead-acid batteries reached 111.1MW. China is the leading producer and country of lead-acid batteries (Wang, 2014). Lithium battery has become the most competitive chemical energy storage technology in the world, and has developed rapidly in recent years, from 2013 2015 years, the global installed capacity of lithium batteries doubled, is the fastest growing 
Table 2. Key Technologies and Development Trend of Energy Storage

\begin{tabular}{|c|c|c|}
\hline $\begin{array}{l}\text { Energy Storage } \\
\text { Technology }\end{array}$ & $\underline{\text { Key Technology }}$ & Technology Development Trend \\
\hline \multirow{4}{*}{$\begin{array}{l}\text { Pumped energy } \\
\text { storage }\end{array}$} & $\begin{array}{l}\text { (1) Site selection technology of Large Pumped Storage } \\
\text { Power station; }\end{array}$ & $\begin{array}{l}\text { (1) Advanced design technology of fluid machinery and whole machine } \\
\text { manufacturing technology of pumped storage power station; }\end{array}$ \\
\hline & (2) High dam engineering technology; & $\begin{array}{l}\text { (2) key technologies such as excavation and support of high dam and super large } \\
\text { underground cavern group under complicated geological conditions; }\end{array}$ \\
\hline & $\begin{array}{l}\text { (3) High water head, large capacity water pump, water } \\
\text { turbine and generator motor technique; }\end{array}$ & $\begin{array}{l}\text { (3) Domestic production of high efficiency and high parameter pumped storage } \\
\text { units; }\end{array}$ \\
\hline & (4) Intelligent scheduling and operation control technology & \\
\hline \multirow{5}{*}{$\begin{array}{l}\text { Compressed air } \\
\text { energy storage }\end{array}$} & (1) Efficient compressor technology; & (1) Wide load multi-stage combined compressor technology; \\
\hline & (2) Expander technology; & (2) High load axial expander technology; \\
\hline & (3) Combustion chamber technology; & (3) Large capacity compact regenerative heat exchanger technology; \\
\hline & (4) Heat storage technology; & $\begin{array}{l}\text { (4) Integration and control technology of advanced compressed air energy storage } \\
\text { system }\end{array}$ \\
\hline & $\begin{array}{l}\text { (5) Gas storage technology; } \\
\text { (6) System integration and control technology }\end{array}$ & \\
\hline \multirow{3}{*}{$\begin{array}{l}\text { Flywheel energy } \\
\text { storage }\end{array}$} & $\begin{array}{l}\text { (1) To improve the energy density of composite materials } \\
\text { technology; }\end{array}$ & $\begin{array}{l}\text { (1) The new flywheel energy storage system based on axial flux permanent magnet } \\
\text { motor; }\end{array}$ \\
\hline & (2) Magnetic bearing technology; & $\begin{array}{l}\text { (2) Research on coordinated operation control technology of energy storage array } \\
\text { and large generator set; }\end{array}$ \\
\hline & (3) Large capacity flywheel energy storage array technology & $\begin{array}{l}\text { (3) Coupling control technology of large capacity flywheel energy storage system in } \\
\text { different power systems }\end{array}$ \\
\hline \multirow{5}{*}{$\begin{array}{l}\text { Superconducting } \\
\text { magnetic energy } \\
\text { storage }\end{array}$} & $\begin{array}{l}\text { (1) High temperature superconducting material technology } \\
\text { and temperature zone control technology; }\end{array}$ & (1) Stabilization technology of large and medium superconducting magnet; \\
\hline & (2) Low temperature refrigeration technology; & $\begin{array}{l}\text { (2) Design, processing and manufacturing technology of low temperature and high } \\
\text { voltage insulation materials; }\end{array}$ \\
\hline & (3) Superconducting current limiting technology; & (3) topology and control strategy of large capacity power converter; \\
\hline & (4) Power conversion adjustment technology; & (4) High efficiency cryogenic refrigeration technology; \\
\hline & (5) System dynamic monitoring technology & (5) Intelligent on-line monitoring technology \\
\hline \multirow{5}{*}{ Lead acid battery } & $\begin{array}{l}\text { (1) Positive and negative pole and gate plate material } \\
\text { technology; }\end{array}$ & (1) Preparation technology of grid plate alloy; \\
\hline & (2) Utilization ratio of active materials; & (2) Positive and negative pole and clapboard material and structure technology; \\
\hline & (3) Consistency between cell monomers; & (3) Battery sealing and maintenance free technology; \\
\hline & (4) Lead substitution technology; & (4) Battery charge management and temperature control technology; \\
\hline & (5) A new generation of VRLA battery technology & $\begin{array}{l}\text { (5) Low resistance and high reliability lead carbon battery electrode plate preparation } \\
\text { technology }\end{array}$ \\
\hline \multirow[b]{3}{*}{ Lithium battery } & (1) Reliability and consistency of battery pack; & (1) Overall design technology of battery system; \\
\hline & $\begin{array}{l}\text { (2) High energy density and high power density lithium } \\
\text { battery scale production technology; }\end{array}$ & (2) Battery system integration and group technology; \\
\hline & $\begin{array}{l}\text { (3) High performance positive and negative materials and } \\
\text { the preparation of safe electrolyte }\end{array}$ & (3) Battery \\
\hline
\end{tabular}

(4) Synthesis of electrode materials with high capacity and good cycle stability;

(5) Optimization technique of electrochemical system;

(6) Power management and thermal management technology

(1) High stability electrolyte preparation technology;

(1) Large scale, high performance and low cost non fluorine ion conducting membrane scale preparation process and batch chemical production Technology

(2) High selectivity low cost ion exchange membrane

Liquid flow cell preparation technology;

(3) High reactive electrode preparation technology $\quad$ (2) High power density reactor engineering and mass assembly manufacturing technology;

(3) Structure design, integration, manufacture and management control of high integration container type battery modüle technique

(1) Solid electrolyte preparation technology; (1) Batch preparation technique of beta alumina ceramic tube;

(2) Battery pack sealing technology; $\quad$ (2) Low cost anti-corrosion electrode material research and development and

(3) Unit module technology and system integration preparation technology;

$\begin{array}{ll}\text { Sodium sulfur } & \text { (3) Unit mod } \\ \text { battery } & \text { technology }\end{array}$

(4) Battery manufacturing process, battery management $\quad$ (3) New water based sodium based energy storage battery technology technology;

(1) Large-scale power electronic interface and high energy (1) research and fabrication of high energy density and high power density density super capacitor electrode material technology; supercapacitors;

$\begin{array}{llll}\text { Ultracapacitor } & \text { (2) New system, high power modular technology; } & \text { (2) research and development of hybrid supercapacitor; }\end{array}$

(3) Commercialization and serialization technologies $\quad$ (3) research and fabrication of composite electrode materials with high specific capacitance, high operating voltage, large power density and long cycle life

application of chemical energy storage technology. At present, the capacity of lithium-ion batteries used in energy storage power plants has reached 64MW H level (Wang et al., 2015; Li et al., 2016). In recent years, the development of liquid flow battery is more stable. The application of vanadium redox flow battery and zinc bromide flow battery is more and more. It is mainly used in the field of large-scale grid connected renewable energy. The main flow battery R \& D institutions including Dalian Rongke Power, Sumitomo electrician, UniEnergy, Technologies, 
European Journal of Sustainable Development Research, 2(3), 31

Table 3. Development Stages of Energy Storage Technology

\begin{tabular}{|c|c|c|c|c|c|c|c|c|c|}
\hline $\begin{array}{l}\text { Energy storage } \\
\text { Technology }\end{array}$ & $\begin{array}{c}\text { Basic } \\
\text { Principle }\end{array}$ & $\begin{array}{l}\text { Concept } \\
\text { Study }\end{array}$ & $\begin{array}{l}\text { Experimental } \\
\text { Study }\end{array}$ & Prototype & $\begin{array}{c}\text { Complete } \\
\text { Test }\end{array}$ & $\begin{array}{c}\text { Simulated } \\
\text { Environment }\end{array}$ & $\begin{array}{c}\text { Real } \\
\text { Enviro- } \\
\text { nment }\end{array}$ & $\begin{array}{c}\text { Setting } \\
\text { Experiment }\end{array}$ & $\begin{array}{l}\text { Commercial } \\
\text { Applications }\end{array}$ \\
\hline Pumped storage & $\sqrt{ }$ & $\sqrt{ }$ & $\sqrt{ }$ & $\sqrt{ }$ & $\sqrt{ }$ & $\checkmark$ & $V$ & $\sqrt{ }$ & $\checkmark$ \\
\hline $\begin{array}{l}\text { Sea water pumped } \\
\text { storage }\end{array}$ & $\sqrt{ }$ & $V$ & $V$ & $\sqrt{ }$ & $V$ & $V$ & & & \\
\hline $\begin{array}{l}\text { Traditional } \\
\text { compressed air } \\
\text { energy storage }\end{array}$ & $\checkmark$ & $\sqrt{ }$ & $\checkmark$ & $\sqrt{ }$ & $\sqrt{ }$ & $\sqrt{ }$ & $\sqrt{ }$ & $\sqrt{ }$ & $\checkmark$ \\
\hline $\begin{array}{l}\text { Supercritical } \\
\text { compressed air } \\
\text { energy storage }\end{array}$ & $\sqrt{ }$ & $\sqrt{ }$ & $\checkmark$ & $\sqrt{ }$ & $\sqrt{ }$ & $\sqrt{ }$ & $\checkmark$ & & \\
\hline $\begin{array}{l}\text { Flywheel energy } \\
\text { storage }\end{array}$ & $\sqrt{ }$ & $\checkmark$ & $\sqrt{ }$ & $\checkmark$ & $\sqrt{ }$ & $\sqrt{ }$ & $\sqrt{ }$ & $\checkmark$ & $V$ \\
\hline Flywheel array & $\sqrt{ }$ & $\sqrt{ }$ & $\sqrt{ }$ & $\sqrt{ }$ & $\sqrt{ }$ & $\sqrt{ }$ & $\sqrt{ }$ & & \\
\hline $\begin{array}{l}\text { Superconducting } \\
\text { magnetic energy } \\
\text { storage }\end{array}$ & $\sqrt{ }$ & $\sqrt{ }$ & $\checkmark$ & $\sqrt{ }$ & $\sqrt{ }$ & $\sqrt{ }$ & $\sqrt{ }$ & & \\
\hline Lead acid battery & $\sqrt{ }$ & $\checkmark$ & $\checkmark$ & $\sqrt{ }$ & $\sqrt{ }$ & 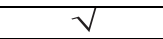 & $\sqrt{ }$ & $\checkmark$ & $\checkmark$ \\
\hline Lead carbon cell & $\checkmark$ & $\checkmark$ & $\checkmark$ & $\checkmark$ & $\checkmark$ & $\checkmark$ & $\checkmark$ & $\checkmark$ & \\
\hline Lithium battery & $\checkmark$ & $\checkmark$ & $\checkmark$ & $\checkmark$ & $\checkmark$ & $\checkmark$ & $\checkmark$ & $\checkmark$ & $\sqrt{ }$ \\
\hline $\begin{array}{l}\text { Vanadium redox flow } \\
\text { battery }\end{array}$ & $\sqrt{ }$ & $\sqrt{ }$ & $\sqrt{ }$ & $\sqrt{ }$ & $\sqrt{ }$ & $\sqrt{ }$ & $\sqrt{ }$ & $\sqrt{ }$ & $\checkmark$ \\
\hline Other flow battery & $\sqrt{ }$ & $\sqrt{ }$ & $\checkmark$ & $\sqrt{ }$ & $\sqrt{ }$ & & & & \\
\hline Sodium sulfur battery & $\sqrt{ }$ & $\sqrt{ }$ & $\sqrt{ }$ & $\checkmark$ & $\sqrt{ }$ & $\sqrt{ }$ & $\sqrt{ }$ & $\sqrt{ }$ & $\sqrt{ }$ \\
\hline Sodium based battery & $\sqrt{ }$ & $\sqrt{ }$ & $\sqrt{ }$ & & & & & & \\
\hline Ultracapacitor & $\checkmark$ & $\checkmark$ & $\checkmark$ & $\checkmark$ & $\sqrt{ }$ & $\checkmark$ & $\checkmark$ & $\checkmark$ & \\
\hline
\end{tabular}

\section{Grid Energy Storage Technologies and Applications}

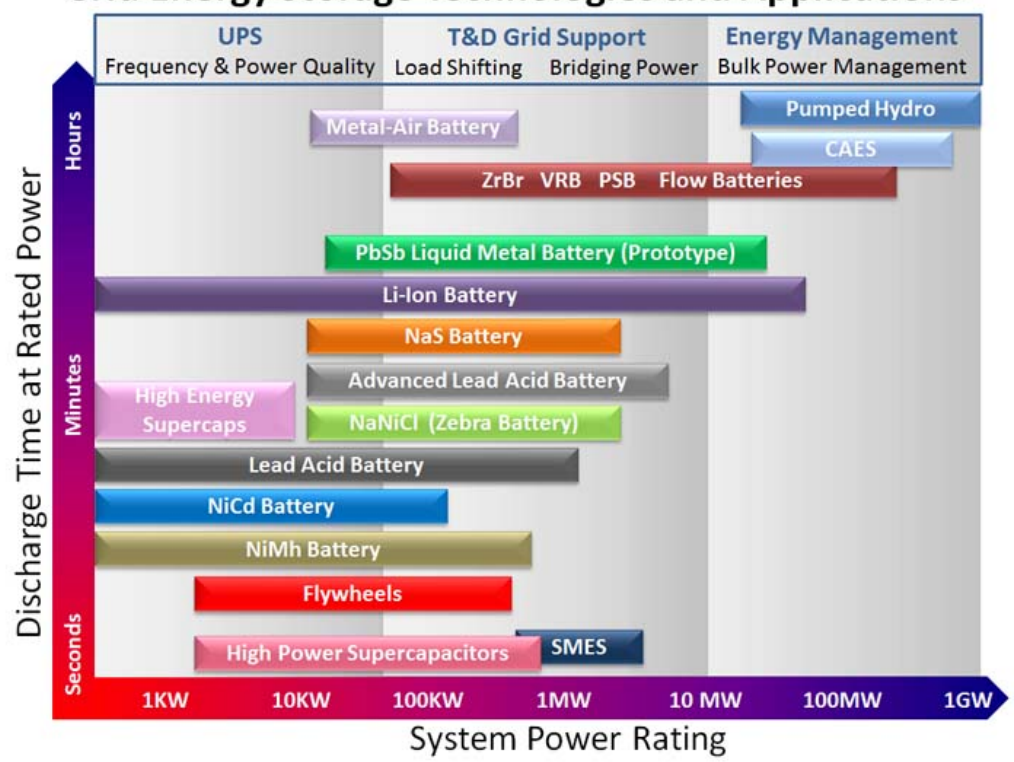

Figure 2. Application Areas of Major Energy Storage Technologies

Imergy, Power, Systems, etc., Among them, the Japanese Sumitomo Electric in 2016 put into operation 15MW / 60MWh liquid flow battery energy storage demonstration power station, it is the largest liquid flow battery energy storage project put into operation at present (Li et al., 2015; Xu et al., 2013; Zhang et al., 2016). The development of sodium sulfur battery is slow in recent three years, and Japan NGK company is the only organization to realize the industrialization of sodium sulfur battery. In 2015, after the NGK company's sodium sulfur battery storage system fire, NGK gradually improved the battery structure and enhanced security research and development. It still leads the development of the global sodium sulfur battery. Chinese Academy of Sciences, Shanghai Silicate Research Institute, China's sodium sulfur battery sector has been in a leading position, in recent years, the battery materials have been gradually improved, and a new generation of sodium sulfur batteries has been developed. It has a strong competitive edge in the field of R \& D of international sodium sulfur batteries. 
Table 4. Application of Energy Storage in Power Industry

\begin{tabular}{ll}
\hline Application Field & Application type \\
& $\begin{array}{l}\text { Auxiliary dynamic } \\
\text { operation }\end{array}$
\end{tabular}

Traditional power generation Main function

In order to maintain the balance between load and generation time, and ensure the large generating units as much as possible in the economic conditions, The energy storage system and operation the generator set can adjust the output size according to the scheduling requirements so as to improve the efficiency and operation cost of the generating set and delay the service life of the generator set.

Replacing or delaying The energy storage equipment is configured under the condition that the power generated by the new units load increase or the unit elimination cannot meet the load, The utility model can be combined with an original generator set to increase the output of the original power generation equipment or indirectly increase the capacity of the original power generation equipment, thereby replacing or delaying the newly-built unit.

When the load is low or the power is limited, the intermittent renewable energy can charge the energy storage device. When the load is high or the power is not limited, the energy storage Peak shaving and valley device can be charged to the grid. This application allows storage and renewable energy as a filling complete system, the output is adjustable and can be scheduled, reduce the standby unit capacity of the power system, the intermittent renewable energy into the grid friendly and can be scheduled.

Renewable
energy pow energy pow
generation

Tracking plan output

Renewable power generation is intermittent and unstable, and its power generation forecasting results cannot be in real-time agreement with the power grid scheduling plan. Because of its fast response and large climbing rate, energy storage can track the planned output and coordinate the power grid scheduling and renewable energy forecasting power, Thereby ensuring the safe and effective absorption of renewable energy power generation.

Plan and tracking output similar to that of the charge and discharge through the energy storage

Climbing rate control system, reduce the output fluctuation of renewable energy in a short period of time, thereby reducing the pressure on power peaking, to ensure safe and stable operation of the power grid.

With the aid of dynamic inverters, communication and control equipment, the energy storage can

Reactive power support adjust the reactive power output of the energy storage system, and then adjust the voltage of the power transmission and distribution lines.

The energy storage system is installed upstream of the blocking circuit, and the energy storage

Link blocking system is charged when the line load exceeds the line capacity, i.e., when the line is blocked, The electrical energy that cannot be transmitted by the line is stored in an energy storage device; When the load is less than the line capacity, the energy storage system discharges to the line.

Transmission and distribution Delaying the expansion and upgrading of power transmission and distribution Use a small capacity storage devices to avoid delay even to expand the capacity of existing transmission and distribution equipment, power transmission and distribution system is mainly applied to the load close to the equipment capacity, in order to delay or avoid expansion, the energy storage system installed downstream needed power transmission and distribution equipment upgrade,

Substation DC power supply

The new type of energy storage equipment enters the substation, providing DC power for signal equipment, relay protection, automatic device, emergency lighting and breaker switching operation.

Frequency modulation Through the energy storage device, the network can be charged and charged quickly and rapidly, and the frequency of the power system is kept in the safe range.

Distributed energy storage devices have the ability to respond quickly, respond quickly to load demands in a matter of seconds, and provide service with loads lasting for more than a few

Voltage support minutes or even $1 \mathrm{~h}$. It can be used to release or absorb reactive power according to the load demand. It can avoid the loss of reactive power in long distance transmission and realize voltage support.

Power grid auxiliary service

Peak shaving

Equipped with a certain energy storage capacity, when the peak load is required to generate electricity, meet the power demand, and achieve the balance of power production and power consumption in the power system.

Reserve capacity $\quad$ The energy storage equipment can provide standby auxiliary service for the grid. By charging and discharging the energy storage equipment, the purpose of regulating the active power balance of the grid can be realized.

When the electricity price is low, the energy storage system is charged, and when the electricity TOU (Time of use) price is high, the discharge can not only reduce the overall electricity cost through the low storage tariff management and high release, And it's not necessary to change the user's power usage, even when the price is the highest, and you can use the electricity according to your own needs.

User side Capacity cost management The user charges the energy storage device according to its power consumption habit during the period when the power load is low, When a high load is needed, the energy storage equipment is used to discharge, thereby reducing the maximum load and reducing the cost of capacity.

Improve power reliability When the power failure occurs, the energy storage system can supply the reserve energy to the end users, so as to avoid the interruption of power supply during the restoration process and to ensure the reliability of the power supply.

The energy storage equipment installed on the load side can maintain the power quality in the

Improve power quality event of short failure, and reduce voltage fluctuations, frequency fluctuations, The effects of power factor, harmonics, and second to minute load disturbances on the power quality.

In recent years, China's energy storage industry has accelerated the pace of development in terms of project planning, policy support and production capacity layout, it can be said Chinese storage industry has gradually exposed spring, is gaining momentum. The development of China's pumped storage industry is relatively slow, while the growth rate of the electrochemical energy storage market is obviously higher than that of the global 
market, while the thermal energy storage is still in its infancy. Thanks to the progress of technology and cost reduction, in the case of subsidies, energy storage in the peak valley spread and auxiliary service market and renewable energy power solutions have achieved commercial operation conditions (Zhang et al., 2016). According to the Zhongguancun energy storage industry technology alliance (CNESA) project library statistics, in 2016, several large-scale projects were planned or put into operation, and the scale of China's newly put into operation energy storage projects was $28.5 \mathrm{MW}$, and the installed capacity of energy storage plants maintained a sustained and rapid growth (Li et al., 2016). At the same time, energy policies have been intensively introduced, and energy storage has gradually become the key areas of planning and layout, local governments will subsequently layout energy storage projects and demonstrations, boosting local industrial transformation and upgrading. In the next few years, with the rapid development of renewable energy industry, the energy storage market will also enjoy rapid growth.

The so-called photovoltaic power generation, according to the principle of solar cell, the presence of the photon for electronic transitions, and potential difference, in this way, the solar energy can be converted into electric energy, which is a direct current. The application of energy storage devices in photovoltaic power stations is similar to that in wind farms, when the output power of the photovoltaic cell fluctuates, the energy storage device can operate immediately, providing instantaneous power to ensure that the device can continue to operate stably. Furthermore, the uncertainty of PV output and short-term forecasting errors can be studied according to statistical theory. In addition, because the battery has a relatively mature technology, high energy density, the price is relatively low, so most of the photovoltaic power station often use battery storage in order to improve the output characteristics of power system. However, because of this storage, method is very simple, there are defects, such as the use of time is not long, the battery power is relatively small etc. Therefore, some studies have shown that hybrid energy storage systems can be applied to meet the relevant requirements (Arslan et al., 2017).

\section{CONCLUSION}

With the growing depletion of fossil fuels and the accelerated growth of energy demand, a new round of technological revolution and industrial change, represented by renewable energy and new energy technologies, is emerging and will continue to change the pattern of world energy. The worldwide energy structure adjustment has become an important issue in the energy sector. Renewable energy and new energy technology, in the current situation, represents not only the development of a new technology. At the same time, it has far-reaching influence on a series of traditional development patterns, such as traditional economic and energy development mode, new manufacturing system and so on.

The future development of energy storage market will mainly focus on distributed energy storage, distributed PV + storage, micro grid and other aspects of the distribution network and the user side. In April 2016, the National Energy Administration announced its plan of action for innovation in energy technology (2016 - 2030), By 2020 the 10MW/100MW h Supercritical compressed air energy storage system and 1MW/1000MJ flywheel energy storage array will be demonstrated and introduced, 100MW class of vanadium redox flow battery energy storage system, $10 \mathrm{MW}$ grade sodium sulfur battery storage system and 100MW lithium-ion battery energy storage system, and a number of mature energy storage technologies will be demonstrated as well (National energy board, 2016). The vanadium redox flow battery system would reach $200 \mathrm{MW} / 800 \mathrm{MWh}$, which would be the largest in world. With the deepening of the power system reform, energy storage will also gain more market opportunities. However, the energy storage industry in China is still in a certain distance from the overall healthy development, and the commercial application of energy storage faces the high cost of energy storage, the market level of the electricity market is not perfect, the energy storage technology route is immature, the energy storage price and the effective incentive are various. Therefore, the development of energy storage industry can be described as opportunities and challenges (Zhongguancun, 2012; Zhongguancun, 2013; Zhongguancun, 2014; Zhongguancun, 2015; Special report, 2016; Rifkin, 2011; Under the State Council, 2015).

\section{ACKNOWLEDGEMENTS}

The authors wish to thank the State Grid Tianjin Energy Saving Service Co., Ltd, China for funding and support this work.

Author Contributions: All authors made a significant contribution to the writing of this manuscript.

Conflicts of Interest: The authors declare no conflict of interest. 


\section{REFERENCES}

Arslan, H., Luo, L. and Bilawal, A. (2017). Demand and Application of Energy Storage Technology in Renewable Energy Power System. American Scientific Research Journal for Engineering, Technology, and Sciences, 36(1), 75-84.

Chen, H., Ding, Y., Peters, T., et al. (2008). A Method ofStoring Energy and a Cryogenic Energy Storage System, CA. 1989400.

Chen, H., Haisheng, C., Yang, W., et al. (2009). Progress in Electrical Energy Storage System-A Critical Review. Progress in Natural Science, 19(3), 291-312. https:/ / doi.org/10.1016/j.pnsc.2008.07.014

Chen, H., Tan, C., Liu, J., et al. (2012). Energy StorageSystem Using Supercritical Air: US. 20120216520.

Chino, K. and Araki, H. (2000). Evaluation of Energy Storage Method UsingLiquid Air.Heat Transfer -Asian Research, 29(5), 347-357. https://doi.org/10.1002/1523-1496(200007)29:5<347::AID-HTJ1>3.0.CO;2-A

Critigino, F., Mohmeyer, K. U., Scharf, R. (2001). Huntorf CAES: More than 20 Years of Successful Operation. Solution Mining Research Institute.

Energy Storage Council. (2002). Energy Storage, the Missing Link in the Electricity Value Chain.

Guo, H., Xu, Y., Chen, H., et al. (2016). Thermodynamic Characteristics of a Novel Supercritical Compressed Air Energy Storage System. Energy Conversion and Management, 115, 167-177. https://doi.org/10.1016/j.enconman.2016.01.051

Habib, A., Arshad, A. and Khan, R. (2017a). Distributed Renewable Energy under the Guidance of Price Autonomous Operation Technology. Smart Grid and Renewable Energy, 8, 305-324. https://doi.org/10.4236/sgre.2017.810020

Habib, A., Sou, C. and Ananta, A. (2017b). Control Strategy of DC Link Voltage Flywheel Energy Storage for Non Grid Connected Wind Turbines Based on Fuzzy Control. Journal of Power and Energy Engineering, 5, 72-79. https://doi.org/10.4236/jpee.2017.511006

International Energy Agency. (2014). Technology Roadmap Energy Storage.

Li, H. and Lu, C. (2015). Summary of basic issues of electrochemical energy storage. Electrochemistry, 21(5), $412-$ 424.

Li, H. and Xu, X. (2016). Solid state lithium battery research, development, vision and strategy. Energy storage science and technology, 5(5), 607-614.

Li, D. (2016). Inventory 2016 in the first half of China's energy storage industry development. High-tech and industrialization 9, 24-27.

Liu, W., Yang, Y., Zhang, X., et al. (2007). Compressed air energy storage (CAES) power station and its present situation and development trend. Shandong electric power technology, 2, 10-14.

Liu, B., Zhang, J., Li, D., et al. (2016). Current status and Prospect of energy storage in peak load regulation and frequency modulation service. Energy storage science and technology, 5(6), 909- 914.

Luo, X., Wang, J., Dooner, M., et al. (2015). Overview of Current Development in Electrical Energy Storage Technologies and the Application Potential in Power System Operation. Applied Energy, 137, 511-536. https://doi.org/10.1016/j.apenergy.2014.09.081

Ma. (2014). Overview of distribution of solar energy resources in China [EB/OL]. Available at: http://www.solarbe.com/topnews/201404/09/1321.html (Accessed 4 September 2014)

Mi, J. (2014). Analysis of the development trend of power industry in the next 5-10 years [EB/OL]. Available at: http://www.sic.gov.cn/News/82/2827.htm (Accessed 27 May 2014)

Ming, D., Zhong, C., Jianhui, S., et al. (2013). Overview of battery energy storage systems in renewable energy power generation. Automation of power systems, 37(1), 19-25, 102.

Nakhamkin, M., Andersson, L., Swensen, E., et al. (1990). AEC110MW CAES Plant; Status of Project.Journal of Engineering for Gas Turbines \& Power, 114(4), 695-700. https:// doi.org/10.1115/1.2906644

National energy board. (2016). National energy board innovation plan for energy technology revolution [EB/OL]. Available at: http://www.nea.gov.cn/2016-06/01/c_135404377.htm

Northwest Institute of Surveying and Design Limited. (2014). Wind energy resources and wind farm development (two) -- meteorological conditions of distribution and influence distribution of wind energy resources in China [EB/OL]. Available at: http://news.bjx.com.cn/html/20140305/494663.shtml (Accessed 3 May 2014)

Rosasa, Liu, Y., Liu, G., et al. (2013). Development and relevant enlightenment of overseas pumped storage power stations. Domestic and foreign energy, 18(11), 26-29.

Rifkin, J. (2011). The Third Industrial Revolution: How Lateral Poweris Transforming Energy. The Economy and the World. New York: Palgrave Macmillan Trade, pp. 24-71.

Special report. (2016). Special report of the National Energy Bureau, guiding opinions on promoting the development of energy storage technology and Industry.

The U.S. Department of Energy. (2011). Energy Storage Planning Document. 
Under the State Council. (2015). The State Council guidance on actively promote the "Internet plus" action. [EB/OL]. Available at: http://www.gov.cn/zhengce/content/2015 -07/04/content_10002.htm

Wang, F. (2014). Current status and future prospects of lead-acid battery market in China. Batteries, 51(4), 171-178.

Wang, X., Zhang, Y., Li, Y., et al. (2015). Development of vanadium redox flow battery technology and industry. Energy storage science and technology, 4(5), 458-466.

Wen, Z., Yu, G., Gu, Z., et al. (2010). Overview of the development and current situation of China's sodium sulfur battery technology. Power supply and utilization, 27(6), 25-28.

Xiaohui, Y., Yujie, X., et al. (2013). Development, prediction and analysis of large-scale energy storage technology in China. China electric power corporation, 46(8), 22-29.

Xu, S., Li, X., and Huidong. (2013). Overview of the development and demonstration of large-scale electrochemical energy storage system. Electric power construction, 34(7), 73-80.

Zhang, C., Ji, J., Jinhua. (2010). Development prospect of pumped storage power station in China under the new situation. China Hydroelectric Power Engineering Society, power grid peaking and pumped storage, Specialized Committee pumped storage Symposium.

Zhang, G., Chen, H., Liu, J., et al. (2012). Advances in compressed air energy storage technology. Energy storage science and technology, 1(1), 26-40.

Zhongguancun. (2012). Zhongguancun energy storage industry technology alliance energy storage. Specialized Committee energy storage industry research white paper.

Zhongguancun. (2013). Zhongguancun energy storage industry technology alliance energy storage Specialized Committee energy storage industry research white paper.

Zhongguancun. (2014). Zhongguancun energy storage industry technology alliance energy storage Specialized Committee energy storage industry research white paper.

Zhongguancun. (2015). Zhongguancun energy storage industry technology alliance energy storage Specialized Committee energy storage industry research white paper.

Zhang, J. (2016). 2015 energy storage market inventory - an industry poised for. Energy storage science and technology, $5(1), 58-64$.

Zhang, J., Dai, W. Y. and Ma, G. (2016). Research on the development trend of sodium sulfur battery based on patent analysis. Modern information, 36(9), 142-150. 